\title{
Extremely high mortality of newborn juveniles in the nursery colony of Myotis myotis at Žihobce, SW Bohemia, Czech Republic (Chiroptera: Vespertilionidae)
}

\author{
Extrémně vysoký úhyn čerstvě narozených mlád'at v mateřské kolonii netopýra \\ velkého (Myotis myotis) v Žihobcích v jihozápadních Čechách \\ (Chiroptera: Vespertilionidae)
}

\section{Jaroslav ČERVENÝ ${ }^{1} \&$ Luděk BUFKA ${ }^{2}$}

${ }^{1}$ Faculty of Forestry and Wood Sciences, Czech University of Life Sciences Prague, Kamýcká 129, CZ-165 00 Praha 6, Czech Republic; cerveny@fld.czu.cz

${ }^{2}$ Administration of the Šumava National Park, Sušická 339, CZ-341 92 Kašperské Hory, Czech Republic; ludek.bufka@npsumava.cz

received on 10 November 2020

\begin{abstract}
In 2020, an extremely high mortality of juveniles was recorded in a nursery colony of Myotis myotis at Žihobce (Klatovy Dist.), reaching 50.6\% of the potential growth. Most juveniles died within two weeks of age (67.4\%). The cause of this phenomenon is not known. The results of chemical analyses carried out in five dead juveniles showed neither the presence of heavy metals nor pesticides in the bodies. The dissection of cadavers revealed a good nutrition state. In all dissected individuals, intestinal inflammation was recorded. Most juveniles in the colony were significantly parasitised. In the period of parturition, it was cold and very rainy for several days, the mortality thus may have been caused by chilling of the juveniles. The effort of females to nurse even the dying juveniles which fell down from the colony was observed. The mortality of juveniles was checked in further 28 control colonies in different parts of the Czech Republic in 2020. At eight sites, making up $27.6 \%$ of all studied sites, the mortality of $10.1-20.0 \%$ was recorded. At the remaining twenty sites ( $69 \%$ of the studied sites), the mortality reached $0-10 \%$. High mortality of juveniles of M. myotis (18.7-39.2\%) was also recorded at Vyšší Brod (Český Krumlov Dist.) in the years 1988-1991. In that case, the probable cause was the application of Lastanox (tributyltin oxide), a toxic chemical used for timber treatment in the colony roost.
\end{abstract}

Key words. Myotis myotis, nursery colonies, juvenile mortality, Czech Republic.

\section{INTRODUCTION}

The greater mouse-eared bat, Myotis myotis (Borkhausen, 1797), is generally considered as an originally cave-dwelling species which uses different man-made structures as daily roosts in the northern part of its distribution range. This applies mainly to the roosts of maternity colonies which are found in the attics of large buildings and churches. In these anthropogenic roosts, environmental conditions are not as constant as in caves, various short-term changes in the character of occurrence can thus occur there more often (see e.g., AUdET 1990, ZAHN 1999, Rodrigues et al. 2003, Postawa \& Gas 2009). They include mainly changes in the size of the nursery colony, different timing of parturitions, abandonment of the roost in case of adverse 
microclimatic conditions, but also a variable mortality of juveniles. In 2020, during the check of the Myotis myotis nursery colony at Žihobce, situated at the foothills of the Šumava Mts., we recorded an unusually high mortality of juveniles at the beginning of the existence of the colony. For that reason, we monitored the colony regularly and tried to reveal the causes of this high mortality, which was quite extraordinary during the whole season.

\section{MATERIAL AND METHODS}

Study sites

In 2020, the nursery colony of Myotis myotis at Žihobce (Plzeň Region) was studied in detail. In addition, data from further 28 colonies in different parts of the Czech Republic were assessed as a control. The list of these sites in geographical order is as follows:

1 Žihobce (Klatovy Dist.), castle tower attic, $49.2144^{\circ} \mathrm{N}, 13.6320^{\circ} \mathrm{E}, 555 \mathrm{~m}$ a. s. 1 ., checks: 8 June 2020 , 23 June 2020, 25 June 2020, 5 July 2020, 14 July 2020, 24 July 2020, 4 August 2020 (leg. L. BufKA, J. ČERVENÝ \& R. ZACHOVÁ);

2 Dolany (Klatovy Dist.), church tower attic, $49.4425^{\circ} \mathrm{N}, 13.2491^{\circ} \mathrm{E}, 375 \mathrm{~m}$ a. s. 1., checks: 8 June 2020 , 8 July 2020 (leg. V. Hanzal \& V. SpurnÝ);

3 Předslav (Klatovy Dist.), church tower attic, $49.4480^{\circ} \mathrm{N}, 13.3547^{\circ} \mathrm{E}, 420 \mathrm{~m}$ a. s. 1 ., checks: 8 June 2020, 8 July 2020 (leg. V. Hanzal \& V. SpurnÝ);

4 Kladruby (Tachov Dist.), a monastery room, $49.7122^{\circ} \mathrm{N}, 12.9955^{\circ} \mathrm{E}, 405 \mathrm{~m}$ a. s. 1., checks: 31 July 2020 (leg. P. TÁJEK \& P. TÁJKOVÁ);

5 Všeruby (Plzeň-sever Dist.), church attic, $49.8419^{\circ} \mathrm{N}, 13.2280^{\circ} \mathrm{E}, 425 \mathrm{~m}$ a. s. 1., checks: 8 June 2020, 8 July 2020 (leg. V. Hanzal \& V. SpurnÝ);

6 Manětín (Plzeň-sever Dist.), church attic, $49.9914^{\circ} \mathrm{N}, 13.2310^{\circ} \mathrm{E}, 415 \mathrm{~m}$ a. s. 1., checks: 8 June 2020, 8 July 2020 (leg. V. Hanzal \& V. SpurnÝ);

7 Radnice (Rokycany Dist.), church tower attic, $49.8576^{\circ} \mathrm{N}, 13.6075^{\circ} \mathrm{E}, 380 \mathrm{~m}$ a. s. 1. , checks: 8 June 2020, 8. 7. 2020 (leg. V. Hanzal \& V. SPuRnÝ);

8 Točník (Beroun Dist.), spaces around staircase, $49.8907^{\circ} \mathrm{N}, 13.8877^{\circ} \mathrm{E}, 440 \mathrm{~m}$ a. s. 1., check: 9 July 2020 (leg. J. Č́ervenÝ, I. HorÁČeK \& D. WeinfurtovÁ);

9 Beroun (Beroun Dist.), school attic, $49.9622^{\circ} \mathrm{N}, 14.0686^{\circ} \mathrm{E}, 230 \mathrm{~m}$ a. s. 1., check: 3-JUly 2020 (leg. D. WeinfurTOVÁ);

10 Dobříšs (Příbram Dist.), castle attic, $49.7819^{\circ} \mathrm{N}, 14.1793^{\circ} \mathrm{E}, 370 \mathrm{~m}$ a. s. 1., check: 2 July 2020 (leg. J. ČERVENÝ \& I. HORÁČEK);

11 Voznice (Př́bram Dist.), highway bridge body, $49.8174^{\circ} \mathrm{N}, 14.2216^{\circ} \mathrm{E}, 375 \mathrm{~m}$ a. s. 1., check: 9 July 2020 (leg. I. HORÁČEK);

12 Kyselka (Karlovy Vary Dist.), house attic, $50.2646^{\circ} \mathrm{N}, 12.9944^{\circ} \mathrm{E}, 360 \mathrm{~m}$ a. s. 1., check: 7 July 2020 (leg. J. MATĚJU゚);

13 Chřibská (Děčín Dist.), church tower attic, $50.8640^{\circ} \mathrm{N}, 14.4826^{\circ} \mathrm{E}, 350 \mathrm{~m}$ a. s. 1., check: 9 July 2020 (leg. J. ČERVEnÝ, D. HorÁČEK, J. KuČERA \& Z. KuČEROVÁ);

14 Cvikov (Česká Lípa dist.), house attic, $50.7766^{\circ} \mathrm{N}, 14.6330^{\circ} \mathrm{E}, 355 \mathrm{~m}$ a. s. 1., check: 9 July 2020 (leg. J. ČERVENÝ, D. HorÁČEK, J. KuČERA \& Z. KuČEROVÁ);

15 Kvítkov (Česká Lípa Dist.), house attic, $50.6544^{\circ} \mathrm{N}, 14.4858^{\circ} \mathrm{E}, 300 \mathrm{~m}$ a. s. 1., check: 9 July 2020 (leg. J. ČERVENÝ, D. HoRÁČEK, J. KuČERA \& Z. KuČEROVÁ);

16 Dubá (Česká Lípa Dist.), house attic, $50.5406^{\circ} \mathrm{N}, 14.5423^{\circ} \mathrm{E}, 265 \mathrm{~m}$ a. s. 1., check: 9 July 2020 (leg. J. ČERVENÝ, D. HORÁČEK, J. KuČERA \& Z. KuČEROVÁ);

17 Ledce (Mladá Boleslav Dist.), house attic, $50.3548^{\circ} \mathrm{N}, 15.0783^{\circ} \mathrm{E}, 255 \mathrm{~m}$ a. s. 1., checks: 4 June 2020, 2 July 2020, 26 July 2020 (leg. J. ČervenÝ, V. Hanzal \& M. Průcha);

18 Opočno (Rychnov nad Kněžnou Dist.), castle attic, $50.2649^{\circ} \mathrm{N}, 16.1154^{\circ} \mathrm{E}, 310 \mathrm{~m}$ a. s. 1. , check: 14 July 2020 (leg. V. LEMBERK); 
19 Doudleby (Rychnov nad Kněžnou Dist.), castle attic, $50.1085^{\circ} \mathrm{N}, 16.2637^{\circ} \mathrm{E}, 290 \mathrm{~m}$ a. s. 1., check: 14 July 2020 (leg. V. LEMBERK);

20 Sruby (Ústí nad Orlicí Dist.), church tower attic, $50.0017^{\circ} \mathrm{N}, 16.1744^{\circ} \mathrm{E}, 285 \mathrm{~m}$ a. s. 1 ., check: 17 July 2020 (leg. V. LEMBERK);

21 Vranová Lhota (Svitavy Dist.), church tower attic, $49.7103^{\circ} \mathrm{N}, 16.8267^{\circ} \mathrm{E}, 290 \mathrm{~m}$ a. s. 1., check: 28 June 2020 (leg. V. LEMBERK);

22 Zvíkovské Podhradí (Písek Dist.), bridge body, $49.4255^{\circ} \mathrm{N}, 14.1951^{\circ} \mathrm{E}, 400 \mathrm{~m}$ a. s. 1., check: 7 July 2020 (leg. R. LUČAN);

23 Kratochvíle (Prachatice Dist.), castle attic, $49.0590^{\circ} \mathrm{N}, 14.1682^{\circ} \mathrm{E}, 435 \mathrm{~m}$ a. s. 1 ., check: 3 July 2020 (leg. L. BufKa \& J. ČERVENÝ);

24 Chvalšiny (Český Krumlov Dist.), church attic, $48.8541^{\circ} \mathrm{N}, 14.2115^{\circ} \mathrm{E}, 570 \mathrm{~m}$ a. s. 1., check: 3 July 2020 (leg. L. BufKa \& J. ČERVENÝ);

25 Zlatá Koruna (Český Krumlov Dist.), monastery attic, $48.8554^{\circ} \mathrm{N}, 14.3712^{\circ} \mathrm{E}, 465 \mathrm{~m}$ a. s. 1., check: 3 July 2020 (leg. L. BufKa \& J. ČERVENÝ);

26 Lesonice (Třebíč Dist.), castle attic, $49.1081^{\circ} \mathrm{N}, 15.7557^{\circ} \mathrm{E}, 520 \mathrm{~m}$ a. s. 1., check: 1 July 2020 (leg. A. Reiter, Z. MAČÁt \& A. TOMAN);

27 Bítov (Znojmo Dist.), castle attic, $48.9435^{\circ} \mathrm{N}, 15.7012^{\circ} \mathrm{E}, 405 \mathrm{~m}$ a. s. 1., check: 1 July 2020 (leg. A. ReIter, Z. MaČÁt \& A. Toman);

28 Jevišovice (Znojmo Dist.), castle attic, $48.9912^{\circ} \mathrm{N}, 15.9887^{\circ} \mathrm{E}, 345 \mathrm{~m}$ a. s. 1., check: 1 July 2020 (leg. A. ReIter, Z. MaČÁt \& A. TOMAN);

29 Znojmo (Znojmo Dist.), church attic, $48.8564^{\circ} \mathrm{N}, 16.0511^{\circ} \mathrm{E}, 255 \mathrm{~m}$ a. s. 1., check: 3 July 2020 (leg. A. REITER).

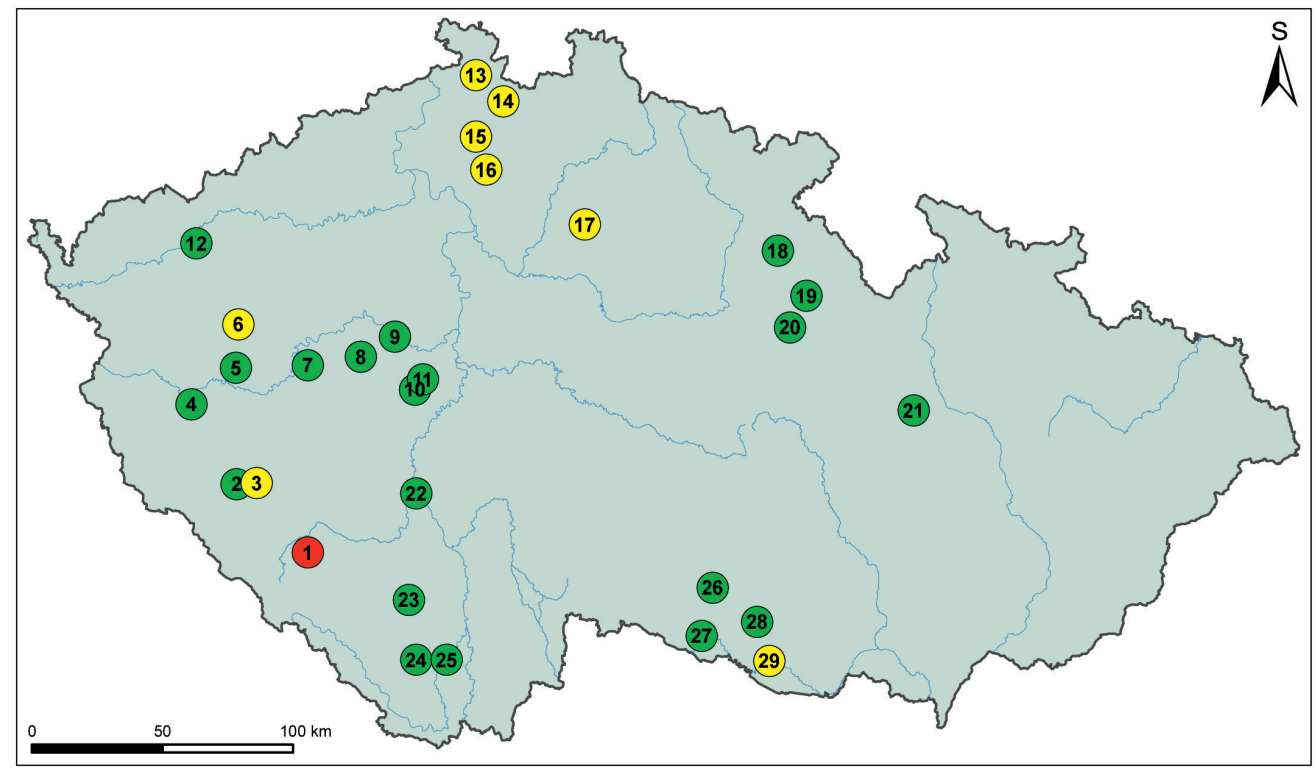

Fig. 1. Map of the sites studied in 2020; green - juvenile mortality reaching $0-10 \%$, yellow $-10.1-20 \%$, red - over $20 \%$.

Obr. 1. Mapa lokalit sledovaných v roce 2020; zeleně - mortalita mlád’at $0-10 \%$, žlutě - 10.1-20\%, červeně - více než $20 \%$. 
Table 1. Numbers of Myotis myotis individuals and the rate of juvenile mortality in the particular colonies (* - data on the number of individuals in the colony are qualified estimates with the accuracy of tens of individuals; ? - only visible individuals were counted from a hidden colony; $\%-\%$ of the aduls)

Tab. 1. Počty jedinců Myotis myotis a výše úhynu mlád’at v jednotlivých koloniích ${ }^{*}$ - údaje o počtu jedinců v kolonii jsou kvalifikované odhady s přesností na desítky kusů; ? - spočítáni pouze viditelní jedinci z ukryté kolonie; $\%$ - \% z počtu dospělých)

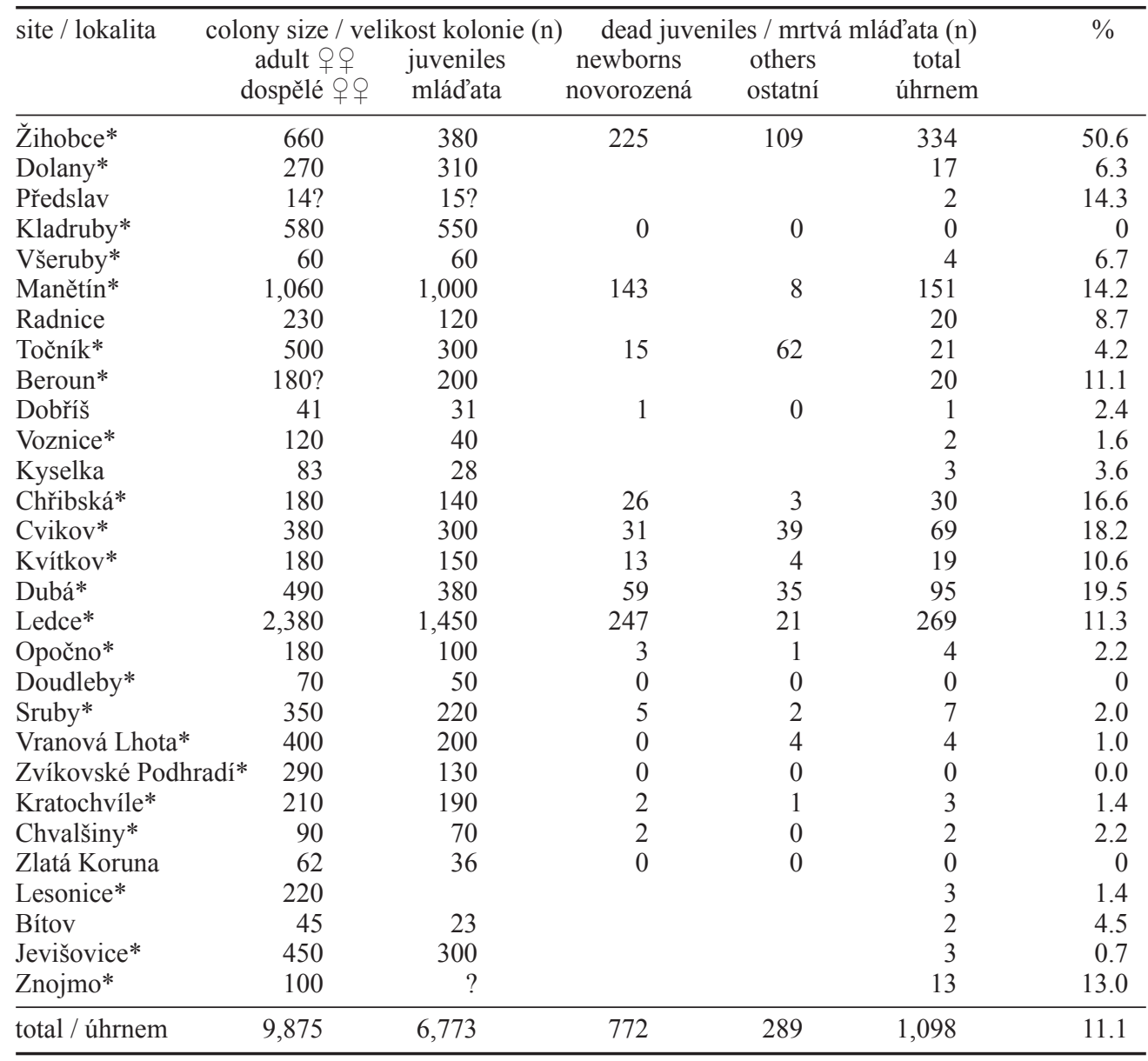

\section{Methods}

At all sites, the numbers of adult females and juveniles were recorded. Dead juveniles were registered in two age categories (sensu SKLENÁR̆ 1962): newborn up to the age of approx. 10 days, and older. For each site, the proportion of live juveniles in the colony and especially the percentage of dead juveniles from the potential growth were recorded. Based on the assumption that each female in the colony has one juvenile (e.g. HorÁČEK 1985, RogeE \& LeHMANN 1994, ZAHN 1998), this proportion is defined as a ratio 
between the number of dead juveniles and the number of adult females. The numbers of individuals in the colonies were determined using photos; in large colonies or in clusters of a complicated distribution, the total number was estimated with the accuracy of tens of individuals.

At the Žihobce site with an enormously high mortality, altogether seven checks were carried out. During each visit, the dead juveniles were removed. On 25 June 2020, five cadavers of juveniles, which died approximately at the age of one week, were taken. Dissection of these cadavers was carried out in the State Veterinary Institute Prague and later on, toxicological analyses aimed at the presence of heavy metals and pesticide residues were performed there too.

\section{RESULTS AND DISCUSSION}

\section{Overall situation}

The map of all 29 studied sites in the Czech Republic is given in Fig. 1. Results from the particular sites are provided in Table 1. The absolutely highest proportion of dead juveniles from the potential growth was recorded at Žihobce (50.6\%), which is $3.4 \%$ of all studied sites. Most juveniles died within two weeks of age there (67.4\%), the other later. At eight sites, making up $27.6 \%$ of all studied sites, the mortality of $10.1-20.0 \%$ was recorded. At the remaining twenty sites $(69 \%$ of the studied sites), the mortality reached $0-10 \%$. These mortality values are in accordance with previously published data (HORÁČEK 1985). This author mentioned the mortality of $5-10 \%$ at long-term studied sites in central Bohemia.

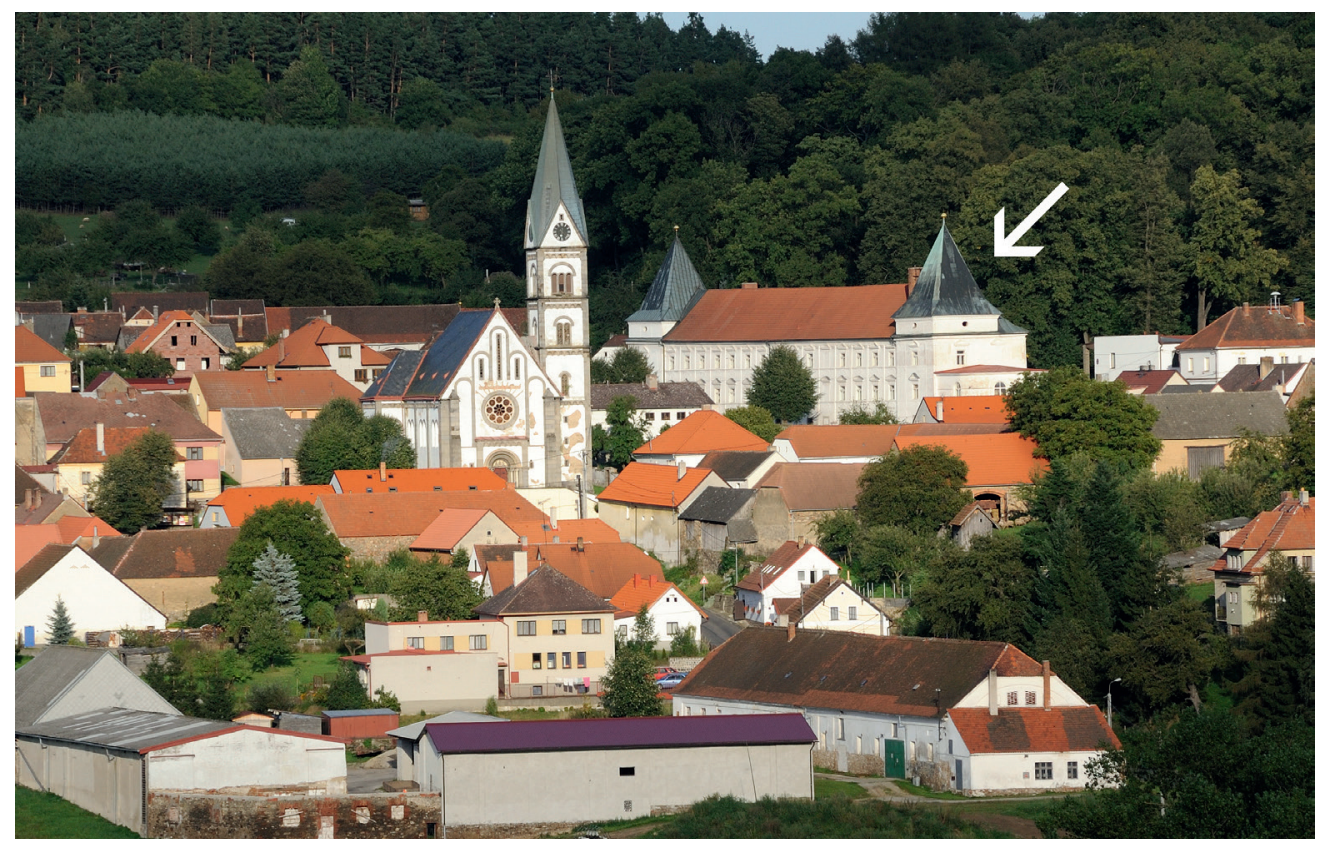

Fig. 2. The Žihobce site (location of the colony roost is indicated by an arrow). Photo by J. ČERVENÝ. Obr. 2. Lokalita Žihobce (šipkou znázorněné umístění kolonie). Foto J. ČERVENÝ. 


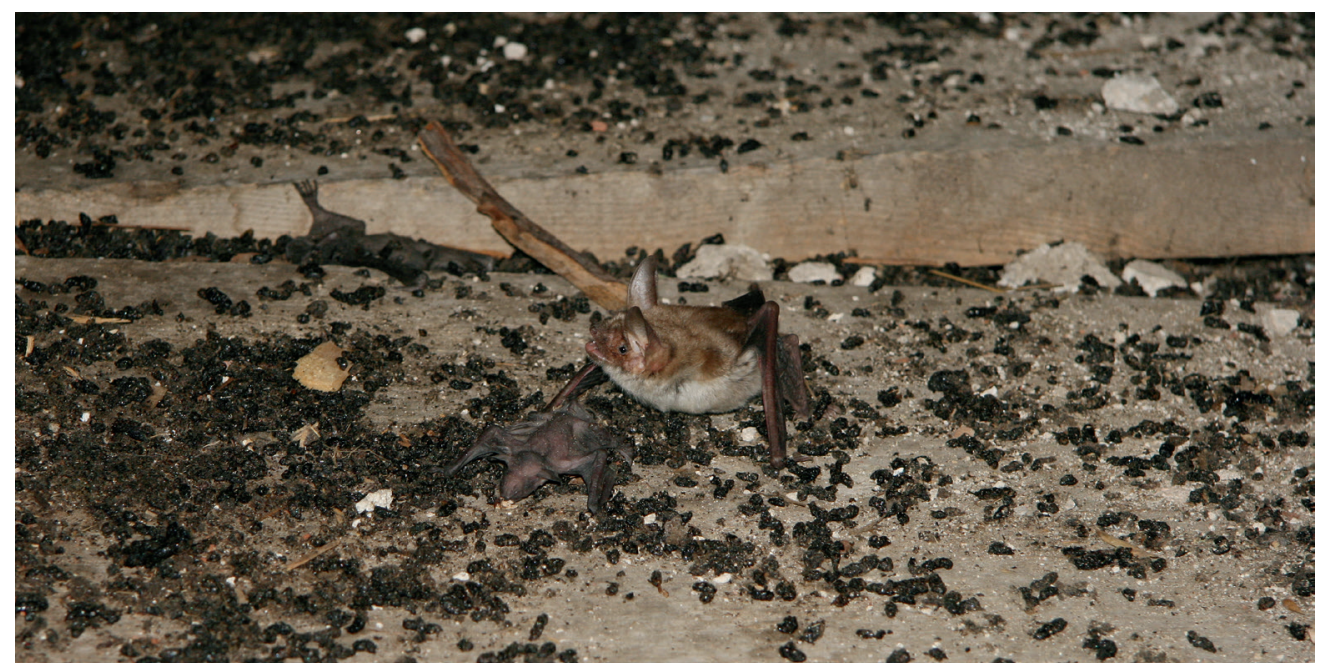

Fig. 3. A female by a dying juvenile on the attic floor under the colony roost, Žihobce, 23 June 2020. Photo by L. BuFKA.

Obr. 3. Samice u hynoucího mláděte na podlaze půdy pod mateřskou kolonií, Žihobce, 23. 6. 2020. Foto L. BUFKA.

In general, the following factors are considered to affect the rate of juvenile mortality in bat nursery colonies:

(a) climatic conditions at the site during the period of parturitions and insufficient termoregulation of the juveniles (e.g. Heidinger et al. 1989, AUdet 1990, ZAHn 1999, Zahn et al. 2007, Postawa \& Gas 2009);

(b) lack of available food for lactating females (e.g. AudEt 1990, ZAHN et al. 2006, 2007);

(c) intoxication of the environment including food sources (e.g. CorRAo et al. 2009, Kunz et al. 1977, ZuKAL et al. 2015);

(d) the level of infestation of bats by ecto- or endoparasites (e.g. CHRISTIE et al. 2000, ZAHN \& Rupp 2004, Frank et al. 2015);

(e) predation by owls, martens, and/or domestic cats (BAuER 1956, Petržílková et al. 2004, Ancillotto et al. 2013, Spitzenberger et al. 2014)

(f) infection situation in the population, mainly concerning viral diseases (e.g. AmENGUAL et al. 2008, DrexLer et al. 2011, He et al. 2014).

\section{$\check{Z}$ i h o b c e}

This site (Fig. 2) situated at the foothills of the Šumava Mts. has been regularly monitored already since the year 1971, when a Myotis myotis colony of 100-150 adult females was found there. The nursery colony then gradually declined and disappeared completely after the year 1986. No increased mortality of juveniles was recorded at that time, however. In the meantime, the site started to serve as a late summer roost for several male harems. In 2019, a nursery colony 
of an unknown origin, with the abundance of about 600 adult females and mortality of 15 juveniles (2.5\%), appeared at the site again. In 2020, the first visit on 8 June showed the presence of 120 females and the first 9 dead juveniles. During the second check on 23 June, the colony size was estimated at 600 females and 60 dead or dying juveniles were recorded, most of them fallen down to the attic floor (Fig. 4). Females approached these juveniles, trying to feed them and encourage them to stay alive (Fig. 3). Two days later, on 25 June, further 155 dead juveniles appeared. During another visit on 5 July, 79 dead juveniles were found, while the number of present adult females increased to 660 individuals. During the fifth check on 14 July, there were further 31 newly dead juveniles. First during the visit on 24 July, no new dead juveniles were recorded. Similarly, the last check of the year carried out on 4 August did not show any new mortality. Because of the cold weather, the whole colony held together and its abundance was determined as 850 adult females and 250 juveniles. In total, at least 334 juveniles died at the site during the breeding season of 2020 , making up $50.6 \%$ of the potential growth. The cause of this phenomenon is not clear. Results of chemical analyses excluded the presence of heavy metals as well as pesticides in the bodies of dead juveniles. The dissection of cadavers proved a good nutrition state. However, intestinal inflammation was recorded in all dissected individuals. The origin of the inflammation (whether it was an infectious colitis) was not studied. Neither the level of infestation by parasites was investigated, but it was significant according to the documentation (see Fig. 5). The effect of a long period of heavy rains at the time of parturitions and consequent lack of milk in the females due to food shortage, or chilling of the juveniles during long absence of the females cannot be excluded either.

The same attic of the castle is currently used also by colonies of other bat species. In the year 1986, a small colony of three individuals of Rhinolophus hipposideros was recorded there for the first time. This colony gradually grew in numbers, reaching almost 200 females in 2020 . Until 2018, the colony used the part of the attic which was occupied by the M. myotis colony in 2019 . The $R$. hipposideros colony thus moved to a more distant part of the attic in that year. In

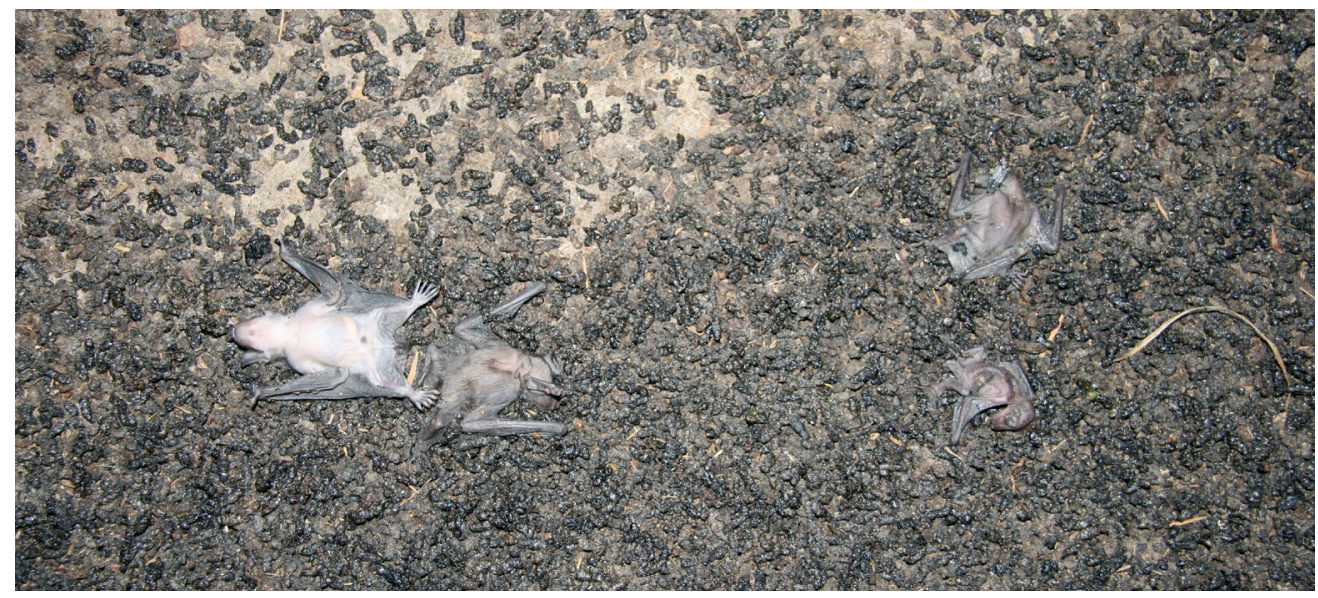

Fig. 4. Dead juveniles, Žihobce, 25 June 2020. Photo by L. BurKA.

Obr. 4. Uhynulá mlád'ata, Žihobce, 25. 6. 2020. Foto L. BuFKA. 


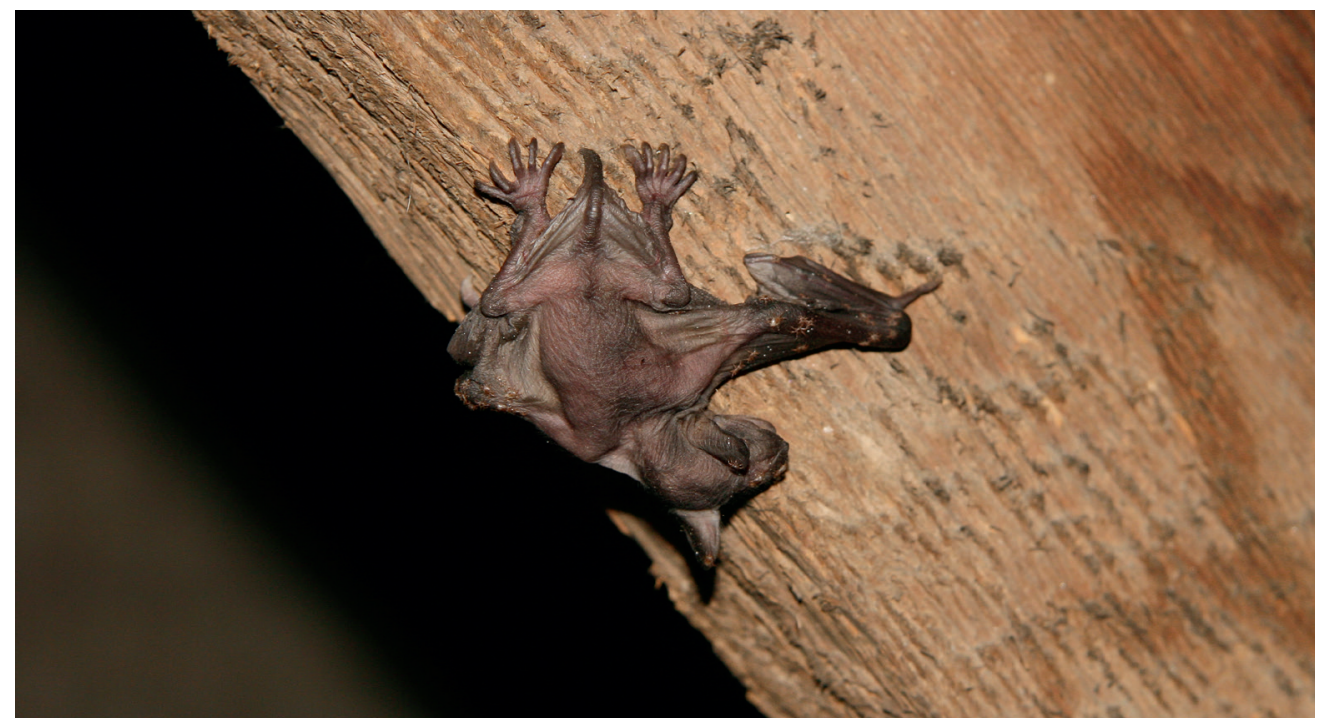

Fig. 5. A juvenile highly infested by parasites, Žihobce, 25 June 2020. Photo by L. BuFKA. Obr. 5. Mládě vysoce napadené parazity, Žihobce, 25. 6. 2020. Foto L. BuFKA.

both 2019 and 2020, only a minumum mortality was registered in the R. hipposideros colony. Myotis nattereri is another species occurring at the site, its colony inhabits different cavities in beam joints. These cavities are also sometimes used by M. myotis individuals, eight inds. of undetermined sex were found in one of them in 2020.

The recorded mortality of M. myotis at Žihobce in the year 2020 is quite unusual. In 2020, extremely high mortality of young of this species was found also in locality Benátky nad Jizerou, which was, however, not the subject of our monitoring. Approximately $32 \%$ of the young died here. In May, the colony had 250 females, beginning July, however, the bats disappeared from the site. During the subsequent inspection, 80 corpses of young of various ages were found (leg. D. Weinfurtová \& E. CepÁková). Somewhat higher mortality was recorded in 2020 in two West Bohemian colonies: Předslav (14.3\%), Manětín (14.2\%), one Central Bohemian colony Ledce (11.3\%) and one South Moravian colony (Znojmo 13.0\%). Of particular interest was the finding of higher mortality of young in four nearby North Bohemian colonies: Chřibská (16.6\%), Cvikov (18.2\%), Kvítkov (10.6\%), and Dubá (19.5\%). Mortality higher than 10\% was recorded also at the Beroun locality (see Fig. 1, Table 1). Here, however, due to the late control on 3 August, a part of the females was probably already missing and besides that, for this colony also predation of bats by the beech marten (Martes foina) is known; so the given value probably does not correspond to reality and is lower (D. WeINFURTOVÁ, ad verb.). High mortality (ČERVENÝ, unpubl. data) was also recorded in the years 1988-1991 at another site in the Šmava foothills, in the attic of the monastery at Vyšš ́ Brod (Český Krumlov Dist.). In 1987, the nowadays forbidden toxic chemical Lastanox (tributyltin oxide) was used there for timber treatment in the colony roost. This resulted not only in serious and persisting health problems in the females (fur loss, bruises, broken veins in auricles and wing membranes, festering inflammations of mammary 
glands), but also in repeatedly high mortality of the juveniles, which reached $39.2 \%$ in the year $1988,19 \%$ in 1990 and $18.7 \%$ in 1991.

\section{SOUHRN}

V mateřské kolonii netopýrů velkých (Myotis myotis) Žihobce (okr. Klatovy) byla v roce 2020 zaznamenána mimořádně vysoká mortalita mlád’at, dosahující hodnoty $50,6 \%$ potencionálního př́růstku (tab. 1). Většina mlád'at uhynula do věku dvou týdnů $(67,4 \%$ ), ostatní později. Př́ičina této skutečnosti není známa. Výsledky chemických analýz u pěti uhynulých mlád’at vyloučily přítomnost jak těžkých kovů, tak i pesticidů v jejich těle. Pitva kadáverů prokázala dobrý výživný stav, u všech pitvaných jedinců však byly zjištěny záněty střev. Většina mlád’at $\mathrm{v}$ kolonii byla značně parazitována. $\mathrm{V}$ době porodů bylo několik dní chladno a silně deštivo, takže př́íčinou úhynů mohlo být i prochlazení mlád’at. Pozorována byla snaha samic kojit i umírající mlád’ata vypadlá z kolonie. Mortalita mlád’at byla v roce 2020 sledována na dalších 28 kontrolních koloniích v různých částech České republiky (obr. 1). Na osmi lokalitách byl zjištěn úhyn $10,1-20 \%$, to představuje $27,6 \%$ ze sledovaných lokalit. Na zbylých dvaceti lokalitách byl zjištěn úhyn $0-10 \%$, což představuje $69 \%$ ze všech sledovaných lokalit. Vysoká mortalita mlád'at $M$. myotis (18,7-39,2 \%) byla zjištěna i v letech 1988 až 1991 na lokalitě Vyšší Brod (okr. Český Krumlov). Zde však bylo příčinou použití jedovaté látky Lastanox (tributylcínoxid) na asanaci dřevěných krovů půdy v místě kolonie.

\section{A c know ledgements}

We would like to thank the following colleagues for their kind help: Eva CEPÁKOVÁ (Praha), Vít DvořÁK (Praha), Vladimír Hanzal (Praha), Daniel HorÁČEK (Liberec), Ivan HorÁČEK (Praha), Roman KovÁŘ (Praha), Zuzana Kučerová (Praha), Jan KučEra (Praha), Vladimír Lemberk (Pardubice), Radek LuČAN (Tehovec), Zdeněk MačÁt (Znojmo), Jan Matěsư (Karlovy Vary), Martin Prưcha (Praha), Jan Rosmus (Praha), Antonín Reiter (Znojmo), Václav Spurný (Plzeň), Přemysl Tásek (Mariánské Lázně), Pavla TÁJKovÁ (Mariánské Lázně), Dita Weinfurtová (Hředle) \& Romana ZachovÁ (Praha).

\section{REFERENCES}

Amengual B., Bourhy H., López-Roig M. \& Serra-Cobo J., 2008: Active monitoring of EBLV infection in natural colonies of the mouse-eared bat (Myotis myotis). Developments in Biologicals, 131: 547-553.

Ancillotto L., Serengeli M. T. \& Russo D., 2013: Curiosity kulled the bat: domestic cats as a bat predators. Mammalian Biology, 78: 369-373.

AUDET D., 1990: Foraging behavior and habitat use by a glaening bat, Myotis myotis (Chiroptera: Vespertilionidae). Journal of Mammalogy, 71: 420-427.

BAUER K., 1956: Schleiereule (Tyto alba Scop.) als Fledermausjäger. Journal für Ornithologie, 97: 335-340.

Christie P., Arlettaz R. \& Vogel P., 2000: Variation in intensity of parasite mite (Spinturnix myoti) in relation to the reproductive cycle and immunocompetence of its bat host (Myotis myotis). Ecology Letters, 3(3): 207-212.

Corrao A., Catalano B. \& Zava B., 2009: Destructive effects of chlorinated pesticides on a bats colony (Chiroptera). Mammalia, 49: 125-130.

Drexler J. F., Corman V. M., Wegner T., Tateno A., F., Zerbinati R. M., Gloza-Rausch F., Seebens A., Müller M. A. \& Drosten C., 2011: Amplification of emerging viruses in a bat colony. Emerging Infectious Diseases, 17(3): 449-456.

Frank R., Kuhn T., Werblow A., Liston A., Kochmann J. \& Klimpel S., 2015: Parasite diversity of European Myotis species with special emphasis on Myotis myotis (Microchiroptera, Vespertilionidae) from a typical nursery roost. Parasites \& Vectors, 8(101): 1-13. 
He X., Korytár̆ T., Zhu Y., Pikula J., Bandouchova H., ZuKal J. \& Köllner B., 2014: Establishment of Myotis myotis cell lines - model for investigation of host-pathogen interaction in a natural host for emerging viruses. Public Library of Science One, 9(10: e109795): 1-10.

Heidinger F., Vogel S. \& Metzner W., 1989: Thermoregulatory behaviour in a maternity colony of Myotis myotis. Pp.: 189-190. In: HANÁK V., HorÁčeK I. \& GAISLER J. (eds.): European Bat Research 1987. Charles University Press, Praha, 720 pp.

HoréČeK I., 1985: Population ecology of Myotis myotis in Central Bohemia (Mammalia: Chiroptera). Acta Universitatis Carolinae - Biologica, 1980: 161-267.

Kulzer E. \& Müller E., 1995: Jugendentwicklung und Jungenmortalität in einer Wochenstube von Mausohren (Myotis myotis) in den Jahren 1986-1993. Veröffentlichungen für Naturschutz und Landschaftspflege in Baden-Württemberg, 70: 137-197.

Kunz T. Z., Anthony E. L. P. \& Rumage W. T., 1977: Mortality in little brown bats following multiple pesticide applications. Journal of Wildlife Management, 41: 476-483.

Petrželková K., Obuch J. \& Zukal J., 2004: Does the barn owl (Tyto alba) selective predate individual great mouse-eared bats (Myotis myotis)? Lynx, n. s., 35: 123-132.

Postawa T. \& Gas A., 2009: Do the thermal conditions in maternity colony roost determine the size of young bats? Comparison of attic and cave colonies of Myotis myotis in southern Poland. Folia Zoologica, 58: 396-408.

Rodrigues L., Zahn A., Rainho A. \& Palmeirim J. M., 2003: Contrasting the roosting behaviour and phenology of an insectivorous bat (Myotis myotis) in its southern and northern distribution ranges. Mammalia, 67: 321-335.

Rogée E. \& Lehmann G., 1994: Beobachtungen zur Biologie und Ursachen der Jugendsterblichkeit beim großen Mausohr in Nordhessen. Pp.: 121-127. In: Arbeitsgemeinschaft für Fledermausschutz in Hessen (ed.): Die Fledermäuse Hessens. Manfred Henneke Verlag, Remshalden, 248 pp.

SKLENÁŘ J., 1962: Poznámky k biologii a postnatálnímu vývoji mlád’at netopýra velkého (Myotis myotis Borkh.) [Notes on the biology and postnatal development of young of the greater mouse-eared bat (Myotis myotis Borkh.)]. Časopis Národního Muzea, Oddíl Přrirodovědný, 130: 26-33 (in Czech).

Spitzenberger F., Engelberger S. \& Kugelschafter K., 2014: Real time observation of Strix aluco preying upon a maternity colony of Myotis emarginatus. Vespertilio, 17: 185-196.

ZAHN A., 1998: Presence of female Myotis myotis in nursery colonies. Zeitschrift für Säugetierkunde, 63: $117-120$.

ZAHN A., 1999: Reproductive succes, colony size and roost temperature in attic-dwelling bat Myotis myotis. Journal of Zoology, London, 247: 275-280.

ZAHN A. \& RupP D., 2004: Ectoparasite load in European vespertilionid bats. Journal of Zoology, London, 262: 383-391.

Zahn A., Rottenwallner A. \& Güttinger R., 2006: Population density of greater mouse-eared bat (Myotis myotis), local diet composition and availability of foraging habitats. Journal of Zoology, London, 269: 486-493.

Zahn A., Rodrigues L., Rainho A. \& Palmeirim J. M., 2007: Critical times of the year for Myotis myotis, a temperate zone bat: role of climat and food resourses. Acta Chiropterologica, 9: 115-125.

Zukal J., Pikula J. \& Bandouchova H., 2015: Bats as bioindicators of heavy metal pollution: history and prospect. Mammalian Biology, 80: 220-227. 